No. 4541 November 10,1956

\section{Chemical Industry in Britain}

IN his Messel Memorial Lecture to the Society of Chemical Industry on October 12, Sir Alexander Fleck, in reviewing some achievements and problems of the chemical industry, referred briefly to the life and work of Messel himself, particularly to his emphasis on the co-operation of science and industry, his insistence that specialization should be based on general education capable of stimulating the imagination and promoting independent thinking, and on the way he spent his working life at Silvertown living among the people who were employed by him. Sir Alexander suggested that if more employers and leaders had done this, the centres of chemical industry might have been made desirable residential neighbourhoods. He laid some stress in conclusion on this aspect of industry, urging that we cannot afford to make our surroundings either a geographical or a cultural desert, and that there must be sociological advance on many fronts, including a general advance in the educational level and a spirit of sincere service to the community. Sir Alexander also emphasized the need both on the management side and on the trade union side for a more flexible organization, capable of understanding current and impending changes; and while such an organization is being built up, the more intimate partnership of the works councils has an important part to play.

Looking at the achievements of the industry, Sir Alexander put the output of sulphuric acid at $2,095,000$ tons in 1955 compared with 800,000 900,000 tons in 1881 , and that of soda ash, soda crystals, caustic soda and sodium bicarbonate, which in 1881 was nearly 600,000 tons, probably exceeded 2 million tons in 1951. The output of dyestuffs had grown from 6,950 tons in 1907 to 42,900 tons in 1951. The average five-and-a-half-fold increase in the real value of production over a large section of the chemical industry in Britain between 1907 and 1951 can be compared with a three-fold increase for manufacturing industry as a whole; over the past five to ten years, the expansion for the whole industry was 9 per cent per annum, compared with 5 per cent for manufacturing industry as a whole.

Finance for the Department of Scientific and Industrial Research

RePlying to a Parliamentary question in the House of Commons on October 23, Mr. J. R. Bevins, Parliamentary Secretary to the Minister of Works, as representing the Lord President of the Council, said that the five-year plan for the expansion of the activities of the Department of Scientific and Industrial Research provides for a financial review in the event of major variations in prices. This review has now taken place, and, subject to annual votes, additional resources will be made available up to March 1959 for grants to research associations and for other purposes. As the Department's receipts for paid services exceed estimates, it will be possible to maintain the number of awards to postgraduate students and other scientific grants during 1956-57.

\section{University of Oxford}

THE issue of the Oxford University Gazette for October 16 gives some interesting statistics on the numbers in residence in the University and their various lines of study. There were 2,463 matriculations in $1954-55$, an inerease of nearly $3 \cdot 7$ per cent on the previous year, and for 1955-56 there were
6,207 men and 1,139 women in residence, making a total of 159 more than last year. The distribution of students under the six headings distinguished by the University Grants Committee is as follows, the first figures referring to men and the second to women: arts, 4,501 and 918 ; science, 1,139 and 163 ; medicine, 282 and 45; technology, 101 and 1 ; agriculture, 98 and 4 ; oversea services probationers, 52 and 1. The numbers of those taking honours schools in scientific or technical subjects in 1956 are as follows: mathematics, 68 ; physics, 74 ; physiology, 69 ; chemistry, 115 (part I) and 77 (part II); zoology, 23; botany, 12 ; geology, 5 ; engineering science, 29 ; geography, 57 ; agriculture, 9 ; forestry, 19 ; psychology, philosophy and physiology, 14; and biochemistry, 6 (part I) and 8 (part II). At Oxford, research students working for either the D.Phil. or B.Sc. in 1956 numbered 218 and 802 , respectively. Though the University population is nearly 50 per cent greater than in 1938, the research side has obviously increased to a very much greater extent since then, for the comparable pre-war figures are: D.Phil., 67; and B.Sc., 78.

\section{Statistics in the University of Sheffield}

Trrodgr the generosity of the United Steel Companies, the University of Sheffield has been able to create an independent Department of Statistics, which began work as such at the beginning of this session. Provision for the teaching of statistics and for research in this field has hitherto been made within the Departments of Mathematics; but the growth of the subject and the very great increase in its use in wide fields of scientific and medical workwhich in turn have meant many calls on the University staff in statistics-have rendered it desirable that a separate department should be established. This was already projected as a future development : the action of the United Steel Companies has made it possible to realize it at once. The head of the new Department, a post which carries the rank of senior lecturer in the University, is Dr. G. H. Jowett, hitherto lecturer in statistics in the University, whose post will be entitled "The United Steel Lectureship".

British Museum (Natural History) : Recent Gifts

THE British Museum (Natural History) has recently received a number of gifts, among which are the following. The Royal College of Surgeons has presented three sub-fossil human skulls from East Africa, thirtyfive miscellaneous human skeletal fragments (mainly limb bones), eight models illustrating eruption of human teeth, and one primate brain-cast. Mr. Angus Booth (University College, Achimota, Gold Coast) has presented a large collection (114 specimens) of monkeys from the Ivory Coast, Gold Coast and Togoland, and four schoolboys have presented the considerable part of a skeleton of the rather rare narrow-nosed rhinoceros, Dicerorhinus hemitoechus Falconer, which they found in a peat deposit on the foreshore at Selsey, Sussex ; further bones have been recovered by officers sent from the Museum, where the remains are being hardened and repaired. The cast of a skull of a child of the Old Stone Age, found with Mousterian flint implements in a cave of TeshikTash in Uzbekistan in 1938, has been received in exchange with the Museum of Anthropology, Moscow State University, and casts of the hand and foot bones of an early Neandertal man from Kiik-Koba, Crimea, have been received in exchange from the Institute of Anthropology, Leningrad, and the Museum 